\title{
ASESMEN DAN INTERVENSI PEDAGOGIK DALAM MEMBANGUN GENERASI EMAS DITINJAU DARI PERSPEKTIF PENGEMBANGAN KREATIVITAS SISWA KELAS AWAL SEKOLAH DASAR
}

\author{
Mohamad Syarif Sumantri \\ Dosen PGSD, PGPUD FIP UNJ, Magister PAUD-Pendas PPs UNJ \\ syarifsumantri@yahoo.com
}

\begin{abstract}
Abstrack : This study intendsto expla in the importance of educating the intervention asesmentand learning in the early grades of primary school, We have to consider the characteristics of the development of elementary schoolage. Intervention can bed one with athemeapproach, this approach is also based on the consideration of developmentally appropriatepractice. Alternative assess mentwould be suitableto monitor the development of students' creativity. Theme as an intervention approach that requiresattention, especially the abilityto educate primary school education for skilled collaborate.
\end{abstract}

Keyword: Intervention, assessment, creativity, early grade of primary education.

\begin{abstract}
Abstrak : Penelitian ini bertujuan untuk menjelaskan pentingnya mendidik asesment intervensi dan belajar di kelas-kelas awal SD. Kita harus mempertimbangkan karakteristik perkembangan usia SD. Intervensi bisa dilakukan dengan pendekatan tema, pendekatan ini juga didasarkan pada pertimbangan praktik sesuai dengan tahapan perkembangan. penilaian alternatif akan cocok untuk memantau perkembangan kreativitas siswa. Tema sebagai pendekatan intervensi yang membutuhkan perhatian, terutama kemampuan untuk mendidik pendidikan sekolah dasar untuk berkolaborasi terampil.
\end{abstract}

Keyword : Intervensi, penilaian, kreativitas, kelas awal pendidikan dasar.

Dalam kehidupan ini kreativitas sangat penting, karena kreativitas merupakan suatu kemampuan yang sangat berarti dalam proses kehidupan manusia. Nilai penting kreativitas dalam kehidupan secara nyata sebagai kemampuan untuk melahirkan sesuatu yang baru yang berupa pikiran maupun karya nyata dalam mengerjakan persoalan hidup bagi orang kreatif. Dengan kreatifnya seseorang dapat melakukan pendekatan secara bervariasi dan memiliki bermacam-macam bentuk kemungkinan penyelesaian terhadap suatu persoalan. Dari potensi kreatifnya, seseorang dapat menunjukkan hasil perbuatan, kinerja/karya, baik dalam bentuk barang maupun gagasan secara bermakna dan berkualitas.

Tingkat kualitas dari kinerja, karya, gagasan, dan perbuatan manusia dapat 
Asesmen Dan Intervensi Pedagogik Dalam Membangun Generasi Emas Ditinjau Dari Perspektif Pengembangan

Kreativitas Siswa Kelas Awal

diantisipasi dari sejauh mana seseorang memiliki tingkat kreativitas tertentu. Dengan kreativitas tinggi yang dimiliki seseorang maka seseorang tersebut akan mempunyai pengembangan diri secara optimal. Mereka dapat mempergunakan ide-idenya untuk menciptakan kreasi baru demi kelangsungan hidup.

Kreativitas penting untuk dipahami bagi para pendidik (guru) terutama dalam kaitannya dengan tugas dan tanggung jawabnya sebagai pendidik dan pengajar dalam membimbing dan "mengantarkan" anak didik kepada pertumbuhan dan perkembangan prestasinya secara optimal.

Penelitian yang dilakukan oleh Leyla Ayverdi dkk, (2007).menunjukan bahwa kreativitas pada siswa SD terutama siswa putra temuannya menunjukan bahwa siswa putrid lebih kreatif dari padaa siswa putra : "The mean general creativity score of girls was found to be statistically significantly higher than that of boys, whereas there was no significant difference between their mean scientific creativity scores. According to the grade level, it was observed that there was a statistically significant difference between the general and scientific creativity scores".

Peningkatan Sumber Daya Manusia dalam era globalisasi dan era reformasi menunjukkan betapa pentingnya segi kreativitas diprioritaskan untuk dikelola dan dikembangkan secara optimal. Dan hal ini merupakan tantangan kepedulian serius bagi pihak terkait dalam pengembangan Sumber Daya Manusia, terutama dikalangan pendidikan.

Kreativitas penting dalam proses belajar mengajar, terutama bagi guru SD. Guru SD diperlukan kemampuan untuk menciptakan suasana yang menyenangkan dan kondusif agar siswa terangsang untuk lebih ingin mengetahui materi, senang menanyakan, dan berani mengajukan pendapat, serta melakukan percobaan yang menuntut pengalaman baru. Hal ini penting bagi guru dalam kegiatan belajar mengajar dengan harapan agar siwa mendapat kesempatan untuk mengukir prestasi secara optimal.

\section{Sedemikan pentingnya}

pengembangan kreativitas terutama pada jenjang siswa usia muda, yang kita pahami usia kelas awal SD adalah susia emas (Golden Ages) dimana semua potensi akan berkembang sangat pesat pada masa itu terutama perkembangan kognitifnya hampir $80 \%$. Diasumsikan bahwa masa emas tersebut memerlukan intervensi pedagogic secara tepat, namum kenyataan dilapangan masih banyak pendidik khususnya di kelas 
awal Sekolah Dasar yang belum menyadari momen penting dalam mengintervensi secara pedagogic. Intervensi dengan langkah asesmen yang diharapkan dapat mencetak generasi emas yang berkualitas ketika mereka berangkat dewasa.

Asesmen merupakan proses sistematika dalam mengumpulkan data seseorang anak yang berfungsi untuk melihat kemampuan dan kesulitan yang dihadapi seseorang saat itu, sebagai bahan untuk menentukan apa yang sesungguhnya dibutuhkan. Berdasarkan informasi tersebut guru akan dapat menyusun program intervensi yang bersifat realitas sesuai dengan kenyataan objektif. Jadi betapa pentingnya peran asesmen yang sangat terkait erat dengan aktivitas atau intervensi.

Selanjutnya dapat dirumuskan masalahnya adalah "Bagaimana peran asesmen dan intervensi pedagogic dalam mengembangkan kreativitas siswa kelas awal SD sebagai generasi emas"?

\section{PEMBAHASAN}

\section{Usia keemasan (Golden Ages) siswa kelas awal SD}

Menurut Santrok (2007) anak yang berada di kelas awal SD adalah anak yang berada pada rentangan usia dini. Masa usia dini ini merupakan masa perkembangan anak yang pendek tetapi merupakan masa yang sangat penting bagi kehidupannya.

Oleh karena itu, pada masa ini seluruh potensi yang dimiliki anak perlu didorong sehingga akan berkembang secara optimal.

Menurut Jalaludin dan Abdulah (2007) karakteristik perkembangan anak pada kelas satu, dua dan tiga SD biasanya pertumbuhan fisiknya telah mencapai kematangan, mereka telah mampu mengontrol tubuh dan keseimbangannya. Mereka telah dapat melompat dengan kaki secara bergantian, dapat mengendarai sepeda roda dua, dapat menangkap bola dan telah berkembang koordinasi tangan dan mata untuk dapat memegang pensil maupun memegang gunting. Selain itu, perkembangan anak dari sisi sosial, terutama anak yang berada pada usia kelas awal SD antara lain mereka telah dapat menunjukkan keakuannya tentang jenis kelaminnya, telah mulai berkompetisi dengan teman sebaya, mempunyai sahabat, telah mampu berbagi, dan mandiri.

Perkembangan anak usia 6-8 tahun dari sisi emosi antara lain anak telah dapat mengekspresikan reaksi terhadap orang lain, telah dapat mengontrol emosi, sudah mampu berpisah dengan orang tua dan telah mulai belajar tentang konsep nilai misalnya benar dan salah. Untuk perkembangan kecerdasannya anak usia 
Asesmen Dan Intervensi Pedagogik Dalam Membangun Generasi Emas Ditinjau Dari Perspektif Pengembangan Kreativitas Siswa Kelas Awal

kelas awal SD ditunjukkan dengan kemampuannya dalam melakukan seriasi, mengelompokkan obyek, berminat terhadap angka dan tulisan, meningkatnya perbendaharaan kata, senang berbicara, memahami sebab akibat dan berkembangnya pemahaman terhadap ruang dan waktu.

Paparan di atas menunjukan bahwa usia kelas awal dianggap sebagai usia keemasan karena pada tahap usia ini seluruh potensinya sedang dalam keadaan berkembang demikian pesat artinya memerlukan intervensi tepat, serius dan hati-hati.

\section{Pembelajaran Tematik}

Menurut Sholeh Hidayat (2013) sesuai dengan tahapan karakteristik perkembangan anak, karakteristik cara anak belajar, konsep belajar dan belajar bermakna, maka kegiatan pembelajaran bagi anak kelas awal SD sebaiknya dilakukan dengan pembelajaran tematik. Pembelajaan tematik adalah pembelajaran tepadu yang menggunakan tema untuk mengaitkan beberapa mata pelajaran sehingga dapat memberikan pengalaman belajar bermakna kepada peserta didik. Tema adalah pokok pikiran atau gagasan pokok yang menjadi pokok pembicaraan (Ratna Megawangi 2008), Dengan tema diharapkan akan memberikan banyak keuntungan, di antaranya: (1) Peserta didik mudah memusatkan perhatian pada suatu tema tertentu; (2) Peserta didik mampu mempelajari pengetahuan dan mengembangkan berbagai kompetensi dasar antar matapelajaran dalam tema yang sama; (3) Pemahaman terhadap materi pelajaran lebih mendalam dan berkesan; (4) Kompetensi dasar dapat dikembangkan lebih baik dengan mengkaitkan matapelajaran lain dengan pengalaman pribadi peserta didik; (5) Peserta didik mampu lebih merasakan manfaat dan makna belajar karena materi disajikan dalam konteks tema yang jelas; (6) Peserta didik lebih bergairah belajar karena dapat berkomunikasi dalam situasi nyata, untuk mengembangkan suatu kemampuan dalam satu mata pelajaran sekaligus mempelajari matapelajaran lain; (7) Guru dapat menghemat waktu karena beberapa mata pelajaran yang disajikan secara tematik dapat dipersiapkan sekaligus dan diberikan dalam dua atau tiga pertemuan, waktu selebihnya dapat digunakan untuk kegiatan remedial, pemantapan, atau pengayaan.

Paparan di atas menunjukan bahwa intervensi pedagogic berbasis tematik merupakan pendekatan yang berlandaskan pertimbangan potensi karakteristik siswa kelas awal SD. Siswa usia ini dalam pandangan gestalis (global) selalu mepersepsikan objek, konsep, 
fenomenanya secara menyeluruh maka diperlukan ikatan melalui "tema-tema".

\section{Kedudukan asesmen dan intervensi}

\section{Pedagogik}

Menurut Gullo (2005) dalam asesmen adalah suatu asesmen yang komprehensif dan melibatkan anggota tim untuk mengetahui kelemahan dan kekuatan yang mana hasil keputusannya dapat digunakan untuk layanan pendidikan yang dibutuhkan anak sebagai dasar untuk menyusun suatu rancangan pembelajaran.

Menurut Mindes dkk (1996) asesmen adalah proses sistematika dalam mengumpulkan data seseorang anak yang berfungsi untuk melihat kemampuan dan kesulitan yang dihadapi seseorang saat itu, sebagai bahan untuk menentukan apa yang sesungguhnya dibutuhkan. Berdasarkan informasi tersebut guru akan dapat menyusun program pembelajaran yang bersifat realitas sesuai dengan kenyataan objektif. Hal lebih operasional dikemukan oleh Bomstein dan Kazdin (1985) dikutip Gullo (2005) asesmen berupaya untu 1) mengidentifikasi masalah dan menyeleksi target intervensi, 2) memilih dan mendesain program treatmen, 3) mengukur dampak treatmen yang diberikan secara terus menerus dan 4) mengevaluasi hasil-hasil umum dan ketepatan dari terapi.

Tujuan asesmen adalah untuk melihat kondisi anak saat itu. Dalam rangka menyusun suatu program pembelajaran yang tepat sehingga dapat melakukan layanan pembelajaran secara tepat. Berdasarkan temuanpenelitian Bernauer (1997) menunjukan bahwa asesmen merupakan bentuk pertanggungjawban pendidik yang dapat mendorong tingkat keberhasilan pendidikan :

“........that assessments for accountability are congruent with our goals and aspirations for students and with what we know to be critical components of successful change and meaningful educational improvement -- especially the recognition that teachers are at the center of such change and improvement.

Menurut Robb (1996) asesmen berfungsi untuk menyaring dan mengidentifikasi anak, 2) untuk membuat keputusan tentang penempatan anak 3) untuk merancang individualisasi pendidikan, 4) untuk memonitor kemajuan anak secara individu, 5) untuk mengevaluasi kefektifan program. Sedangkan Menurut Sumardi \& Sunaryo (2006) memperoleh data yang relevan, objektif, akurat dan komprehensif tentang kondisi anak saat ini :

1) Mengetahui profil anak secara utuh terutama permasalahan dan hambatan belajar yang dihadapi, potensi yang 
Asesmen Dan Intervensi Pedagogik Dalam Membangun Generasi Emas Ditinjau Dari Perspektif Pengembangan Kreativitas Siswa Kelas Awal

dimiliki, kebutuhan-kebutuhan khususnya, serta daya dukung lingkungan yang dibutuhkan anak

2) Menentukan layanan yang dibutuhkan dalam rangka memenuhi kebutuhankebutuhan khususnya dan memonitor kemampuannya.

Berdasarkan hasil kajian di atas menunjukan bahwa asesmen dilakukan dalam memahami anak pada saat tertentu baik potensi-potensinya maupun kelemahan-kelemahan yang dimiliki anak sebagai bahan untuk menyusun program intervensi secara tepat.

\section{Tinjauan Asesmen kelas awal SD pada kurikulum 2013}

Pemerintah telah memberlakukan kurikulum baru yang disebut dengan Kurikulum 2013. Kurikulum, proses pembelajaran, dan asesmen proses dan hasil belajar merupakan komponen penting dalam kegiatan pembelajaran disamping komponen-komponen yang lain. Komponen tersebut saling terkait antara satu dengan yang lain. Kurikulum adalah seperangkat rencana dan pengaturan mengenai tujuan, isi, dan bahan pelajaran serta cara yang digunakan sebagai pedoman penyelenggaraan kegiatan pembelajaran untuk mencapai tujuan pendidikan tertentu. Proses pembelajaran merupakan upaya untuk mencapai Kompetensi Dasar yang dirumuskan dalam kurikulum. Sementara itu, kegiatan asesmen dilakukan untuk mengukur dan menilai tingkat pencapaian Kompetensi Dasar. Asesmen juga digunakan untuk mengetahui kekuatan dan kelemahan dalam proses pembelajaran, sehingga dapat dijadikan dasar untuk pengambilan keputusan, dan perbaikan proses pembelajaran yang telah dilakukan. Oleh sebab itu kurikulum yang baik dan proses pembelajaran yang benar perlu di dukung oleh sistem asesmen yang baik, terencana dan berkesinambungan.

Menurut Ibrahim Bafadal (2013) asesmen merupakan serangkaian kegiatan untuk memperoleh, menganalisis, dan menafsirkan data tentang proses dan hasil belajar peserta didik yang dilakukan secara sistematis dan berkesinambungan, sehingga menjadi informasi yang bermakna dalam pengambilan keputusan. Dengan diberlakukannya kurikulum 2013 yang menekankan pada pembelajaran berbasis aktivitas, maka penilainnya lebih menekankan pada asesmen proses baik pada aspek sikap, pengetahuan, dan keterampilan.

Asesmen pada siswa kelas awal SD menfokuskan perhatian pada hal-hal sebagai berikut.

1) Asesmen diarahkan untuk mengukur pencapaian kompetensi dasar pada KI3 dan KI-4. 
2) Asesmen menggunakan acuan kriteria; yaitu berdasarkan apa yang bisa dilakukan peserta didik setelah mengikuti proses pembelajaran, dan bukan untuk menentukan posisi seseorang terhadap kelompoknya.

3) Sistem yang direncanakan adalah sistem asesmen yang berkelanjutan. Berkelanjutan dalam arti semua indikator ditagih, kemudian hasilnya dianalisis untuk menentukan KD yang telah dimiliki dan yang belum, serta untuk mengetahui kesulitan peserta didik.

4) Hasil asesmen dianalisis untuk menentukan tindak lanjut. Tindak lanjut berupa perbaikan proses pembelajaran berikutnya, program remedi bagi peserta didik yang pencapaian kompetensinya di bawah ketuntasan, dan program pengayaan bagi peserta didik yang telah memenuhi ketuntasan.

5) Sistem asesmen harus disesuaikan dengan pengalaman belajar peserta didik yang ditempuh dalam proses pembelajaran. Misalnya, jika pembelajaran menggunakan pendekatan tugas observasi lapangan maka evaluasi harus diberikan baik pada proses misalnya teknik wawancara, maupun produk berupa hasil melakukan observasi lapangan. a) Karakteristik Asesmen

Sesuai dengan Pedoman Penilaian yang diterbitkan Kemendiknas (2013) bahwa asesmen memiliki karakteristik sebagai berikut:

1. Belajar Tuntas

Asumsi yang digunakan dalam belajar tuntas adalah peserta didik dapat mencapai kompetensi yang ditentukan, asalkan peserta didik mendapat bantuan yang tepat dan diberi waktu sesuai dengan yang dibutuhkan. Peserta didik yang belajar lambat perlu diberi waktu lebih lama untuk materi yang sama, dibandingkan peserta didik pada umumnya.

Untuk kompetensi pada kategori pengetahuan dan keterampilan (KI-3 dan KI-4), peserta didik tidak diperkenankan mengerjakan pekerjaan atau kompetensi berikutnya, sebelum mampu menyelesaikan pekerjaan dengan prosedur yang benar dan hasil yang baik.

2. Otentik

Memandang asesmen dan pembelajaran adalah merupakan dua hal yang saling berkaitan.Asesmen otentik harus mencerminkan masalah dunia nyata, bukan dunia sekolah. Menggunakan berbagai cara dan kriteria holistik (kompetensi utuh 
Asesmen Dan Intervensi Pedagogik Dalam Membangun Generasi Emas Ditinjau Dari Perspektif Pengembangan

Kreativitas Siswa Kelas Awal

merefleksikan

pengetahuan,

keterampilan, dan sikap). Asesmen

otentik tidak hanya mengukur apa yang

diketahui oleh peserta didik, tetapi lebih menekankan mengukur apa yang dapat dilakukan oleh peserta didik.

3. Berkesinambungan

Asesmen berkesinambungan dimaksudkan sebagai asesmen yang dilakukan secara terus menerus dan berkelanjutan selama pembelajaran berlangsung. Tujuannya adalah untuk mendapatkan gambaran yang utuh mengenai perkembangan hasil belajar peserta didik, memantau proses, kemajuan, dan perbaikan hasil terus menerus dalam bentuk asesmen proses, dan berbagai jenis ulangan secara berkelanjutan.

4. Menggunakan teknik asesmen yang bervariasi

Teknik asesmen yang dipilih dapat berupa tertulis, lisan, produk, portofolio, unjuk kerja, projek, pengamatan, dan asesmen diri.

5. Berdasarkan acuan kriteria

Kemampuan peserta didik tidak dibandingkan terhadap kelompoknya, tetapi dibandingkan terhadap kriteria yang ditetapkan, misalnya ketuntasan minimal, yang ditetapkan oleh satuan pendidikan masing-masing. b) Jenis Asesmen

Asesmen pendidikan sebagai proses pengumpulan dan pengolahan informasi untuk mengukur pencapaian hasil belajar peserta didik mencakup asesmen otentik, asesmen diri, asesmen berbasis portofolio, ulangan, ulangan harian, ulangan tengah semester, dan ulangan akhir semester yang diuraikan sebagai berikut.

1. Asesmen otentik merupakan asesmen yang dilakukan secara komprehensif untuk menilai aspek sikap, pengetahuan, keterampilan mulai dari masukan (input), proses, sampai keluaran (output) pembelajaran. Asesmen otentik bersifat alami, apa adanya, tidak dalam suasana tertekan.

2. Asesmen diri merupakan asesmen yang dilakukan sendiri oleh peserta didik secara reflektif untuk membandingkan posisi relatifnya dengan kriteria yang telah ditetapkan.

3. Asesmen berbasis portofolio merupakan asesmen yang dilaksanakan untuk menilai keseluruhan entitas proses belajar peserta didik termasuk penugasan perseorangan dan/atau kelompok di dalam dan/atau di luar kelas dalam kurun waktu tertentu.

4. Ulangan merupakan proses yang dilakukan untuk mengukur pencapaian kompetensi peserta didik secara berkelanjutan dalam proses 
pembelajaran, untuk memantau kemajuan dan perbaikan hasil belajar peserta didik.

5. Ulangan harian merupakan kegiatan yang dilakukan secara periodik untuk menilai kompetensi peserta didik setelah menyelesaikan satu sub-tema. Ulangan harian terintegrasi dengan proses pembelajaran lebih untuk mengukur aspek pengetahuan, dalam bentuk tes tulis, tes lisan, dan penugasan.

6. Ulangan tengah semester merupakan kegiatan yang dilakukan oleh pendidik untuk mengukur pencapaian kompetensi peserta didik setelah melaksanakan $8-9$ minggu kegiatan pembelajaran.

7. Ulangan akhir semester merupakan kegiatan yang dilakukan oleh pendidik untuk mengukur pencapaian kompetensi peserta didik di akhir semester.

c) Pengertian intervensi Pedagogik Intervensisering dikatkan dengan istilah lain dengan kegiatan pembelajaran yang dilakukan pada siswa berkebutukan khusus (ABK) maka selanjutnya intervensipun dapat dimaknai sebagai perpaduan dari dua aktivitas, yaitu aktivitas mengajar dan aktivitas belajar. Aktivitas mengajar menyangkut peranan seorang guru dalam konteks mengupayakan terciptanya jalinan komunikasi harmonis antara pengajar itu sendiri dengan si belajar. Belajar merupakan suatu bentuk pertumbuhan atau perubahan diri seseorang yang dinyatakan dalam caracara bertingkah laku yang baru, berkat pengalaman dan latihan. Pengertian lain belajar yaitu suatu proses usaha yang dilakukan seseorang untuk memperoleh suatu perubahan tingkah laku yang baru secara keseluruhan, sebagai hasil pengalamannya sendiri dalam interaksi dengan lingkungannya. Slameto, (2003:2).

Ciri-ciri dari intervensi menurut Sugandi, dkk (2000:25) antara lain:

1. Intervensi dilakukan secara sadar dan direncanakan secara sistematis;

2. Intervensi dapat menumbuhkan perhatian dan motivasi siswa dalam belajar;

3. Intervensi dapat menyediakan bahan belajar yang menarik dan menantang bagi siswa;

4. Intervensi dapat menggunakan alat bantu belajar yang tepat dan menarik;

5. Intervensi dapat menciptakan suasana belajar yang aman dan menyenangkan bagi siswa;

6. Intervensi dapat membuat siswa siap menerima pelajaran baik secara fisik maupun psikologis.

Pengertian pedagogik adalah berupa bimbingan yang diberikan dengan sengaja oleh orang dewasa kepada anak atau orang 
Asesmen Dan Intervensi Pedagogik Dalam Membangun Generasi Emas Ditinjau Dari Perspektif Pengembangan Kreativitas Siswa Kelas Awal

lain yang belum dewasa, disebut pendidikan (pedagogik). Setelah itu pedagogik berarti suatu usaha yang dijalankan oleh seseorang atau sekelompok orang untuk mempengaruhi seseorang atau sekelompopk orang lain menjadi dewasa atau tingkat hidup dan penghidupan yang lebih tinggi.

Dalam bentuk lain, pedagogik itu dipandang sebagai suatu proses atau aktifitas yang bertujuan agar tingkah laku manusia mengalami proses tersebut mendapat perubahan. Tingkah laku seseorang adalah setiap respons yang dapat dilihat atau diperlihatkan oleh orang lain.

Disamping itu pedagogik juga merupakan suatu ilmu, sehingga orang menyebutnya ilmu pedagogik. Ilmu pedagogik adalah ilmu yang membicarakan masalah atau persoalan-persoalan dalam pendidikan dan kegiatan-kegiatan mendidik, antara lain seperti tujuan pendidikan, alat pendidikan, cara melaksanakan pendidikan, anak didik, pendidik dan sebagainya.

Selanjutnya menurut Megawangi (2008) prinsip intervensi pedagogic siswa kelas awal SD perlu memperhatikan beberapa hal yang berhubungan dengan usia perkembangan meraka adalah intervensi yang:

1. Bermakna (meaningful)

2. Integratif (integrative)
3. Berbasis nilai (value based)

4. Menantang (challenging)

5. Aktif (Active)

6. Pengembangan berbagai potensi dasar siswa kelas awal SD

a) Dorongan ingin tahu (sense of curiosity)

b) Minat-perhatian (sense of ineterst)

c) Dorongan membuktikan kenyataan (sense of reality)

d) Dorongan menemukan sendiri (sense of discovery)

e) Dorongan bertualang (sense of adventure)

f) Dorongan menghadapi tantangan (sense of challenge)

7. Keberagaman latar belakang lingkungan sosial siswa

8. Kesinambungan dan tahapan perkembangan sosial siswa

Sesuai dengan tahapan karakteristikperkembangan anak,menurut Keenan dan Even (2009) karakteristik cara anak belajar, konsep belajar dan belajar bermakna, maka kegiatan intervensi bagi anak kelas awal SD sebaiknya dilakukan dengan intervensi tematik. Pembelajaan tematik adalah intervensi tepadu yang menggunakan tema untuk mengaitkan beberapa mata pelajaran sehingga dapat memberikan pengalaman belajar bermakna kepada peserta didik. Tema adalah pokok pikiran atau gagasan pokok yang menjadi 
pokok pembicaraan (Keanen dan Evan, 2009). Dengan tema diharapkan akan memberikan banyak keuntungan, di antaranya: (1) Peserta didik mudah memusatkan perhatian pada suatu tema tertentu; (2) Peserta didik mampu mempelajari pengetahuan dan mengembangkan berbagai kompetensi dasar antar matapelajaran dalam tema yang sama; (3) Pemahaman terhadap materi pelajaran lebih mendalam dan berkesan; (4) Kompetensi dasar dapat dikembangkan lebih baik dengan mengkaitkan matapelajaran lain dengan pengalaman pribadi peserta didik; (5) Peserta didik mampu lebih merasakan manfaat dan makna belajar karena materi disajikan dalam konteks tema yang jelas; (6) Peserta didik lebih bergairah belajar karena dapat berkomunikasi dalam situasi nyata, untuk mengembangkan suatu kemampuan dalam satu mata pelajaran sekaligus mempelajari matapelajaran lain; (7) Guru dapat menghemat waktu karena beberapa mata pelajaran yang disajikan secara tematik dapat dipersiapkan sekaligus dan diberikan dalam dua atau tiga pertemuan, waktu selebihnya dapat digunakan untuk kegiatan remedial, pemantapan, atau pengayaan.

Berdasarkan paparan di atas maka dapat disintesakan bahwa asesmen intervensi pedagogic merupakan suatu proses atau aktifitas yang bertujuan agar tingkah laku siswa kelas awal mengalami proses untuk mendapat perubahan. Tingkah laku siswa kelas awal adalah setiap respons yang dapat dilihat atau diperlihatkan oleh orang lain. Selanjutnya pelaksanaan Intervensi adalah proses yang memberikan kepastian bahwa proses belajar mengajar telah memiliki guru dan sarana prasarana yang diperlukan, sehingga dapat membentuk kompetensi dan mencapai tujuan yang diinginkan melalui rangkaian asesmen Identifikasi kesenjangan antara apa yang seharusnya dengan kondisi yang sebenarnya.

Pada tahap dimana guru dan siswa untuk mengenali, menyatakan dan merumuskan kebutuhan belajar, sumbersumber yang tersedia dan hambatan yang mungkin dihadapi dalam kegiatan intervensi untuk memenuhi kebutuhan belajar.

Identifikasi kebutuhan bertujuan antara lain untuk melibatkan dan memotivasi siswa agar intervensi dirasakan sebagai bagian dari kehidupan dan mereka merasa memilikinya.

\section{Apa dan mengapa kreativitas di kelas awal SD?}

Kreativitas merupakan suatu bidang kajian yang kompleks, yang menimbulkan berbagai perbedaan pandangan. Perbedaan definisi kreativitas yang dikemukakan oleh banyak ahli merupakan definisi yang saling melengkapi. Sudut pandang para ahli 
Asesmen Dan Intervensi Pedagogik Dalam Membangun Generasi Emas Ditinjau Dari Perspektif Pengembangan Kreativitas Siswa Kelas Awal

terhadap kreativitas menjadi dasar perbedaan dari definisi kreativitas. Definisi kreativitas tergantung pada segi penekanannya, kreativitas dapat didefinisikan kedalam empat jenis dimensi sebagai Four P's Creativity, yaitu dimensi Person,Proses, Press dan Product.

Dimensi person adalah upaya mendefinisikan kreativitas yang berfokus pada individu atau person dari individu yang dapat disebut kreatif.

Conny (2008) menerangkan bahwa kreativitas merupakan kemampuan atau kecakapan yang ada dalam diri seseorang, hal ini erat kaitannya dengan bakat. Sedangkan Hulbeck menerangkan bahwa tindakan kreatif muncul dari keunikan keseluruhan kepribadian dalam interaksi dengan lingkungannya.Dimensi proses upaya mendefinisikan kreativitas yang berfokus pada proses berpikir sehingga memunculkan ide-ide unik atau kreatif.

Munandar (1999) menerangkan bahwa kreativitas adalah sebuah proses atau kemampuan yang mencerminkan kelancaran, keluwesan (fleksibititas), dan orisinalitas dalam berpikir, serta kemampuan untuk mengelaborasi (mengembangkan, memperkaya, memperinci), suatu gagasan. Pada definisi ini lebih menekankan pada aspek proses perubahan (inovasi dan variasi).
Dimensi Press, pendekatan kreativitas yang menekankan faktor press atau dorongan, baik dorongan internal diri sendiri berupa keinginan dan hasrat untuk mencipta atau bersibuk diri secara kreatif, maupun dorongan eksternal dari lingkungan sosial dan psikologis. Mengenai "press" dari lingkungan, ada lingkungan yang menghargai imajinasi dan fantasi, dan menekankan kreativitas serta inovasi. Kreativitas juga kurang berkembang dalam kebudayaan yang terlalu menekankan tradisi, dan kurang terbukanya terhadap perubahan atau perkembangan baru.

Dimensi Product merupakan upaya mendefinisikan kreativitas yang berfokus pada produk atau apa yang dihasilkan oleh individu baik sesuatu yang baru/original atau sebuah elaborasi/penggabungan yang inovatif.

Definisi yang berfokus pada produk kreatif menekankan pada orisinalitas, seperti yang dikemukakan oleh Conny (2008) yang menyatakan bahwa kreatifitas adalah kemampuan untuk menghasilkan/menciptakan sesuatu yang baru. Begitu pula menurut Haefele (1962) dalam Munandar, 1999; yang menyatakan kreativitas adalah kemampuan untuk membuat kombinasi-kombinasi baru yang mempunyai makna sosial. Dari dua definisi ini maka kreatifitas tidak hanya membuat sesuatu yang baru tetapi mungkin saja 
kombinasi dari sesuatu yang sudah ada sebelumnya.

Dari beberapa uraian mengenai kreativitas yang dikemukakan diatas dapat disimpulkan bahwa : "Kreativitas adalah proses konstruksi ide yang orisinil (asli), bermanfaat, variatif (bernilai seni) dan inovatif (berbeda/lebih baik)".

Keterkaitan asesmen dan intevensi pedagogic dengan profil siswa SD kelas awal sebagai usia emas dalam mengembangkan kreativitasnya, berdasarkan paparan di atas maka dapat dikemukakan hubungan antara asesmen dan intervensi serta kreativitas siswa kelas awal SD; Menurut Conny (2008) dalam meningkatkan kompetensi kreatif siswa kelas awal SD diperlukan suatu langkah awal yaitu memahami karakteristik perkembangan siswa, dilanjutkan dengan melakukan asesmen awal sebagai bahan dasar dalam mengembangkan program intervensi pedagogic yang diperlukan secara tepat baik secara individu maupun secara klasikal yang jelah dalam mengembangkan kreativitas memerlukan prasyarat yaitu:

1. Menciptakan Lingkungan di dalam kelas yang Mmrangsang belajar keatif

a) Memberikan pemanasan

Pemberian pemanasan dapat dilakukan dengan memberikan pertanyaan terbuka, dan bukan pertanyaan tertutup, dimana siswa tinggal menjawab ya atau tidak. Selain itu juga bisa mendorong siswa mengajukan pertanyaan sendiri terhadap suatu masalah.

b) Pengaturan fisik Pengaturan fisik atau ruang kelas saat belajar juga dapat mempengaruhi suatu proses belajar kreatif. Pengaturan fisik di kelas harus bisa disesuaikan dengan kebutuhan dalam menunjang intervensi jadi lebih efektif.

c) Kesibukan di dalam kelas

Umumnya situasi belajar kreatif lebih banyak menuntut siswa untuk aktif melakukan kegiatan fisik dan diskusi. Maka dari itu guru harus dapat membedakan antara kesibukan yang aktif dan diskusi yang produktif dengan kesibukan dan diskusi yang sekedar 'mengobrol'.

d) Guru sebagai fasilitator

Peran guru harus terbuka, mendorong siswa untuk aktif belajar dapat menerima gagasan siswa, memupuk siswa untuk member kritik membangun dan mampu memberikan asesmen terhadap diri sendiri, menghindari hukuman atau celaan terhadap ide yang tidak biasa, dan menerima perbedaan 
Asesmen Dan Intervensi Pedagogik Dalam Membangun Generasi Emas Ditinjau Dari Perspektif Pengembangan Kreativitas Siswa Kelas Awal

menurut waktu dan kecepatan setiap siswa dalam menuangkan ide-ide barunya.

2. Mengajukan dan Mengundang Pertanyaan

Pertanyaan yang merangsang pemikiran kreatif adalah pertanyaan divergen (terbuka), karena memiliki banyak kemungkinan jawaban. Pertanyaan semacam ini membantu siswa mengembangkan keterampilan mengumpulkan fakta, merumuskan hipotesis, dan menguji atau menilai informasi mereka. Agar tampak manfaatnya, pertanyaan terbuka harus mencakup bahan yang cukup dikenal siswa. Oleh karena itu, guru pun disarankan untuk tetap berada dalam jalur tujuan instruksional dari suatu pokok pembahasan.

Dilain pihak peran guru juga sangat penting karena ia harus sebagai fasilitator yang dapat mengenalkan masalah dan memberikan informasi yang diperlukan siswa untuk membahas masalah. Selain itu guru juga harus tahu pada saat kapan peran sertanya diperlukan.

3. Ciri kemampuan berpikir kreatif

Ciri ini adalah (1) keterampilan berpikir lancar (lancar mengajukan pertanyaan dan gagasan, banyak gagasan atau satu masalah, dapat dengan cepat melihat kesalahan atau kejanggalan dari suatu objek, (2) keterampilan berpikir luwes (member perimbangan atas berbagai situasi, pemberian penjelasan/interpretasi yang berbeda atas suatu masalah, menerapkan suatu konsep dengan cara yang berbeda), (3) keterampilan berpikir orisinal (mampu memikirkan masalah yang tidak terpikirkan orang lain, cara pendekatan atau pemikiran melalui pendekatan baru),(4) keterampilan merinci, (5) keterampilan menilai.

Berdasarkan paparan di atas jelas bahwa peran asesmen dan intervensi pedagogic dalam upaya meningkatkan kreativitas siswa kelas awal SD sangan berkaitan; jenis asesmen apa yang tepat untuk memahami perkembangan mereka dan intervensi apa yang cocok dalam mengemnbagkan potensi kreatifnya. Hal tersebut dimungkinkan akan mendorong generasi emas dimasa datang.

\section{SIMPULAN}

Asesmen intervensi pedagogik di SD kelas awal sebagai bagian dari sistem pembelajaran dapat mengembangkan potensi kreativitas siswa dan melalui pendekatan intervensi yang menekankan proses belajar, asesmen dan intervensi pedagogik juga sebagai komponen strategi 
deengan mempertimbangkan pemahaman terhadap karakteristik siswa kelas awal SD.

Pemantauan proses perkembangan kreatifitas siswa kelas awal SD dapat dilakukan dengan aneka bentukasesmen otentik, asesmen diri, dan asesmen berbasis portofolio serta ulangan yang selanjutnya menjadi bahan refleksi untuk mwelakukan intervensi pedagogic pada siswa baik secara klasiskal maupun personal.

Kreativitas siswa kelas awal dapat berkembang optimal dengan menyediakan ragam lingkungan yang kondusif melalui prinsip menciptakan kelas yang merangsang belajar kreatif,dukungan keterampilan guru dalam berkomunikasi melalui pertanyaan terbuka serta mendorong siswa mengajukan pertanyaan sendiri (reflektif) terhadap suatu masalah. Pengaturan fisik atau ruang kelas saat belajar juga dapat mempengaruhi suatu proses belajar kreatif. Pengaturan fisik di kelas perlu disesuaikan dengan kebutuhan siswa dalam yang menunjang intervensi jadi lebih efektif sehingga pada gilirannya kreatifitas siswa menjadi optimal. Kesibukan siswa di kelas dalam situasi belajar kreatif lebih banyak menuntut siswa untuk aktif melakukan kegiatan mental dan fisik dapat melalui interaksi diskusi. Peran guru sebagai fasilitator yang mendorong siswa untuk aktif kreatif, guru dapat menerima gagasan siswa, guru perlu memupuk siswa untuk memberi kritik membangun dan siswa perlu berlatih melakukan asesmen terhadap diri sendiri (self assessment), menghindari hukuman atau celaan terhadap ide yang tidak biasa, dan menerima perbedaan menurut waktu dan kecepatan setiap siswa dalam menuangkan ide-ide barunya. Mengajukan dan mengundang pertanyaan yang merangsang pemikiran aktif kreatif dengan pertanyaan terbuka karena memiliki banyak kemungkinan jawaban.

Intervensi pedagogik di kelas awal SD dapat dilakukan melalui pendekatan tematik (terpadu) karena cocok sebagai andasan pertimbangan kegiatan yang sesuai dengan perkembangan usia emas siswa (Development Appropriate Practices) namum guru SD membutuhkan komitmen dan pemikiran strategis bahwa pendekatan intervensi pedagogic berbasis tematik ini terimplementasi secara efektif yang pada gilirannya dapat memacu-memicu penyiapan generasi emas Indonesia dimasa datang.

\section{DAFTAR RUJUKAN}

Borich D. Garry (1996). Effective Teaching Method. Columbus: Merrill an imprint of Prentice Hall.

Conny R.Semiawan (2008). Penerapan Pembelajaran Pada Anak. Jakarta: PT Indek. 
Asesmen Dan Intervensi Pedagogik Dalam Membangun Generasi Emas Ditinjau Dari Perspektif Pengembangan Kreativitas Siswa Kelas Awal

Gullo F.Dominic (2005). Understanding Assessment and Evaluation in Early Childhood Education. New York: Teacher College Press

Jalaludin dan Abdullah (2007). Filsafat

Pendidikan. Jogyakarta: Arr Ruzz Media Group

Ibrahim Bafadal (2013). Panduan Penilaian Sekolah Dasar. Jakarta: Kemendiknas

Keenan Thomas dan Subhadra Evans (2009). An Introduction to Child Development. London: Sage Foundation of Psychology.

Mindes Gayle dkk (1996). Assessing Young Children. Washington: Delmar Publisher

Utami Munandar (1999). Kerativitas Keberbakatan. Jakarta: Rosda karya

Ratna Megawangi (2008). Pendidikan Holistik. Indonesia Cisalak: Herritage Foundation -dkk (2004). Pendidikan yang patut dan menyenangkan. Indonesia Cisalak: Herritage Foundation

Sholeh Hidayat. (2013) Pengembangan Kurikulum Baru. Jakarta. Rosda

Suryabrata Sumardi (2006). Psikologi Pendidikan. Jakarta: PT RajaGrafindo Persada

Santrock John (2007). Psikologi Pendidikan. Dalllas: Kencana
Sugandi, Achmad, dkk. 2004. Teori Pembelajaran. Semarang: UPT MKK UNNES.

Slameto. 2003. Belajar dan Faktor-Faktor Yang Mempengaruhinya. Jakarta: Rineka Cipta.

http://unsilster.com. pengertian-asesmen. diakses 8 April 2014

http://search.ebscohost.com. Leyla Ayverdi dkk, (2007) Journal : Determination of the Relationship between Elementary Students' Scientific Creativity and Academic Achievement in Science and Technology Courses.

http://search.ebscohost.com. Title: Teaching Improvisation in Elementary General Music: Facing Fears and Fostering Creativity. By: Whitcomb, Rachel, Music Educators Journal, 00274321, Mar2013, Vol. 99, Issue 3

http://search.ebscohost.com. Title: How school communities can help redefine accountability assessment. By: Bernauer, James A., Cress, Katherine, Phi Delta Kappan, 00317217, Sep 97, Vol. 79, Issue 1 http://search.ebscohost.com. Andrej Šorgo $\mathrm{dkk}$, a cross-national study of prospective elementary and science teachers' creativitystyles. Journal of baltic science education, vol. 11, no. 3,201 